\title{
HET GEDEELTE BATANG-WELERI VAN DEN GROOTEN POSTWEG OP JAVA.
}

DOOR

Ir. L. V. JOEKES.

(met een kaartje)

In deel 100 van de Bijdragen tot de Taal-, Land- en Volkenkunde van Nederlandsch-Indië schrijft de heer R. A. Kern in zijn artikel „Met den Gouverneur-Generaal op Reis in 1822” op blz. 290, „De postweg van Batang naar Weleri, het eerste station op Samarangsche bodem, liep veel zuiderlijker dan tegenwoordig, hij ging voor een groot deel door toen nog Vorstenlandsch gebied („Delimas” Solosch, Limpoeng Boeloe en Tersana Jogjasch)".

In het in 1829 verschenen anonieme boekje „Lettres de Java, ou Journal d'un voyage dans cette île, en 1822' dat door den heer Kern in bovengenoemd artikel wordt besproken, vinden we over dat weggedeelte het volgende vermeld: „Un joli chemin, planté dárbres, nous ,conduisit à Batang, cheflieu du district de ce nom. Là le pays devint ,,boisé et montagneux, de sorte qu'il fallut le secours de buffles pour ,gravir différent passages de la route, laquelle, peu après, se dirige ,au sud, et passe par le district Delimas, appartenant au territoire de „l'empereur, et par les districts Tersonno, Boulo et Limpong fesant „partie des pays du sultan de Djocjokarta”.

Aan de hand van de mij tot nu toe bekende gegevens zal hieronder de geschiedenis van dit weggedeelte worden nagegaan en aangetoond dat de door den heer Kern op grond van een uitlating van den anoniemen briefschrijver getrokken conclusie omtrent den vroeger meer zuidelijken loop van den grooten postweg niet juist is.

Uit de reizen van Dr. de Haan van Tegal naar Mataram in 1622 en 1623 blijkt dat toen de weg van Batang naar Soebah ongeveer dezelfde richting had als de tegenwoordige. Van Soebah ging de reis naar Pakis en vandaar over het gebergte naar Kedoe. Hij week hier dus in zuidelijke richting af.

Dr. de Haan schrijft: „De wegen waren doorgaans schoon afge- 
",houwen en over de rivieren en moerassen waren bruggen tegen onze „,komst gemaakt, te weten onder van balken en daar van gevlochten „riet een deksel over, zeer bequam om over te komen” ${ }^{1}$ ).

De bovengenoemde route was die naar Mataram terwijl voor het verkeer tusschen Batavia en Semarang die langs de kust meer was aangewezen. Oorspronkelijk liep deze kustweg door het gebied van den Soesoehoenan. Bij het contract van 11 November 1743 met den Soesoehoenan gesloten werd bij Art. 9 sub 3o aan de Oost-Indische Compagnie behalve de strandregentschappen een strook van 600 roeden (en niet 6000 zooals vermeld staat in Dr. H. T. Colenbrander Koloniale Geschiedenis deel II blz. 195) „langs het strand der zee en langs den oever van alle in zee uitloopende rivieren op en rondom geheel Java" afgestaan ${ }^{2}$ ).

Op den 27sten Mei 1808 geeft de Maarschalk Daendels aan den Resident van Pekalongan opdracht den weg door die residentie te verbeteren en luidt deze: ,Is besloten den resident te Paccalongang te ,gelasten gelijk dezelve gelast word bij dezen, om den grooten weg ,loopende van 't Oost- tot het Westeinde zijner residentie te doen „,brengen in dien staat dat dezelve in beide seizoenen voor allerlei „soorten van transporten bruikbaar worde bevonden, zullende ten ,dien einde de weg op alle plaatsen, waar het terrein zulks maar ,eenigszins zal permitteeren, moeten getrokken worden op eene ,,breedte van twee roeden Rhijnlandsch ( 2 maal $3,767 \mathrm{~m}=7,53 \mathrm{M}$.) ,tonrond gelegt en aan beide zijden met sufficiente gruppen voorzien ,zijn om door het afkomend of stilstaand water niet te worden be,schadigd; met last aan denzelven om dit bovengenoemd werk zonder ,,betaling door de ingezetenen te laten verrichten; doch alzoo aan de ,hoogtens van den berg van Padang (Batang?) een buitengewone , arbeid zal moeten worden besteed om dezelve in die helling en ,glooijing te brengen dat allerhande rij- en voertuigen denzelven ,kunnen passeren wordt aan denzelven totdat einde uit 's Lands kas ,toegelegd rds. 2000 zilvergeld om daaruit deze buitengewone dag"gelden te kunnen voldoen".

„Het geschikste middel om met de minste kosten dezen weg zoo-

1) Jhr. Mr. J. K. J. de Jonge en M. L. van Deventer. De Opkomst van het Nederlandsch Gezag in Oost-Indië IVe deel blz. 293 en Ve deel blz. 31, zie ook het kaartje van P. M. van Milaan. Beschouwingen over het $17 \mathrm{e}$ eeuwsche Mataramse wegennet, Sociaal Geographische Mededeelingen 1942 No. 4 blz. $218 / 19$.

2) P. W. Filet De verhouding der Vorsten op Java tot de Ned. Ind. Regeering 1895 blz. 67, Corpus Diplomaticum V, blz. 365. 
,danig aan te leggen zal zijn dat de resident al het hout tusschen „,den weg en het zeestrand doe wegkappen, alvorens hij zich nopens „de rigting van den nieuwen weg bepale, welke omkapping in allen „gevallen voor den aanleg van nieuwe koffij-tuinen zijn voordeel zal ",hebben".

„Zullende hij verder zorgen dat op elke 400 roeden een paal worde ,gesteld welke de distantiën aanwijst en tevens dienen moet om het ,gewoon onderhoud van den weg onder de districten en ingezetenen „,te verdeelen" ${ }^{3}$ ).

Uit deze opdracht van Daendels blijkt dat hier sprake is van het verbeteren van een bestaanden weg.

Op de Geographische Landkaart opgenomen door den Vaandrig Ingenieur H. C. Cornelius, den Cadet Wm Berg en eenige scholieren van ,het Marine school” te Semarang is deze weg aangegeven en heeft dezelfde richting als de oude postweg van Daendels. Waar de weg vlak langs de kust loopt zijn daarop eenige wachthuizen aangegeven $^{4}$ ).

De kaart is niet gedateerd maar in het Naamboek der Hooge Regeering van 1806 wordt Cornelius vermeld als luitenant benoemd in 1803 (blz. 95) en Wm Berg is in 1806 reeds extra ordin. luitenant (blz. 65). De kaart moet dus dateeren van voor of van 1803 en behoort mogelijk tot een van die waarvoor N. Engelhard in 1802 opdracht gaf ${ }^{5}$ ).

De loop van den postweg volgt uit de opgegeven verspanningsplaatsen nl. bij paal 30 Weleri, paal 34 en 38 ongenoemd, paal 42 Kadawong, paal 48 ongenoemd, paal 53 Oedjong Goenong aan de westzijde en paal 58 nabij de negorij Batang ${ }^{6}$ ).

In 1817 zijn de verspanningsplaatsen Welerie, Karang Anjer?, Passangrahan, Boekoh?, Roban, Oedjong Goenong en Batang op onderlingen afstand gelegen van respectivelijk 4, 5, 5, 5, 4 en 5 paal $^{7}$ ).

Uit de rapporten van den prefect van Pekalongan van December 1808 tot en met Februari 1809 blijkt dat het gedeelte dat het meeste

3) Mr. J. A. van der Chijs Nederlandsch Indisch Plakaatboek deel $14 \mathrm{blz} .770$.

4) 1e Supplement van den Inventaris der Verzameling Kaarten berustende in het Rijksarchief in den Haag 1914 No. 494.

5) Nicolaus Engelhard Overzigt van den Staat der Nederlandsch Oost Ind. Bezittingen onder den G.G. H. W. Daendels 1816 blz. 62 en 290.

6) Mr. H. W. Daendels Memorie over den Staat der Ned. O. I. Bezittingen 1808-1811 Bij1. 2 Org. Stukken Batavia, Wegen en Pasterijen No. 59 Lit. B do 21 Slagtmaand 1810 .

7) Staatsblad van N. I. 1817 No. 27. 
werk vereischte was gelegen bij Kadawong waarvoor zoowel heerendienstplichtigen als kettinggangers werden gebezigd ${ }^{8}$ ).

Medio Mei 1809 wordt opdracht gegeven „de rijst tot spijziging ,van de werklieden die aan den arbeid aan de wegen in de prefecture „,van Pekalongan worden geëmploijeerd hun af te staan tegen 30 „,rijksd. zilver de kojang” " $)$.

Dat de weg nog lang niet goed in orde was blijkt wel uit het volgende: „De stations van paal 30 Welerie tot 42 Kadawong zijn om „,de menigvuldige hoogtens en laagtens en de zware weg bij de minste „regenbui op 4 paal afgedicht kunnende zoodra die weg naar behooren „, is opgemaakt met 2 bespanningen worden bereden (nu drie)" ${ }^{10}$ ).

Uit de rapporten blijkt dat het werkvolk veel aan ziekten leed. Zoo wordt 31 December 1808 opgegeven dat van de 90 kettinggangers ca. 50 en op 7 Januari $1809 \pm{ }^{2 / 3}$ ziek zijn ${ }^{11}$ ).

De aanleg van dit weggedeelte heeft vele menschenlevens gekost. Het aantal dat wordt opgegeven loopt echter sterk uiteen en varieert van $3000^{12}$ ) en $4000^{13}$ ) tot eenige honderdduizenden ${ }^{14}$ ).

Vermoedlijk zullen de twee eerste getallen afkomstig van Raffles en Thorn wel dichter bij de waarheid zijn dan het laatste van de Vaynes van Brakel die van overleveringen spreekt. Ook Nicolaus Engelhard een heftig tegenstander van Daendels spreekt slechts van eenige duizenden die zouden zijn omgekomen aan de wegen over de Megamendoeng (Poentjak) en het bosch van Weleri samen ${ }^{15}$ ).

Behalve de ongezondheid van het $\mathrm{zg}$. bosch van Kadawoeng kleefde aan dit weggedeelte door zijn loop vlak langs de kust nog andere bezwaren nl. 1o. het groote gevaar dat het verkeer over den weg door een landing van den vijand zeer gemakkelijk verbroken kon worden wat het trouwens met een groot gedeelte van den postweg gemeen had en 20 . dat de weg langs het strand herhaaldelijk door zeeroovers werd onveilig gemaakt.

8) 's Lands Oudarchief te Batavia, bundel B. O. W. No. 4.

9) Van der Chijs, Plakaatboek, deel 15 blz. 760.

10) Daendels Staat der N. O. I. Bezittingen Bijl. 2 Org. Stukken Batavia, Wegen en Posterijen No. 59 do 21 Slagtmaand 1810.

a1) 's Lands Oudarchief te Batavia bundel B. O. W. No. 4 lett. j en o.

12) Java Gouvernement Gazette Sat. 4 December 1813 No. 93.

13) W. Thorn Memoir of the Conquest of Java 1815 blz. 283.

14) Jhr. R. G. B. de Vaynes van Brakel De Verdediging van Ned. Ind. 1859 1e stuk blz. 282.

15) N. Engelhard Overzigt van den Staat der N. O. Ind. Bezittingen op den G.G. H. W. Daendels 1816 blz. 147. 
Verschillende malen deden zeeroovers landingen bij Oedjoeng Goenoeng, roofden de menschen, verbranden de poststations en maakten daardoor gedurende verscheidene dagen de weg weinig zeker ${ }^{16}$ ). In 1845 beproefden zij zelfs nog een landing op de kust van Batang doch werden daar door de pradjoerits (gewapende Inlandsche macht) overvallen en verdreven ${ }^{\mathbf{1 7}}$ ).

Daendels schijnt dan ook reeds het voornemen te hebben gehad den weg meer zuidelijk te verleggen ${ }^{18}$ ).

Daartegen bestond echter een groot bezwaar daar volgens het contract met den Soesoehoenan van 11 November 1743 slechts een strook langs de kust ter breedte van 600 Rijnl. roeden of $2260 \mathrm{~m}$. uit gouvernements gebied bestond. Bij een verlegging zou de weg loopen door de zg. Djabarangkahscke landen behoorende tot het gebied der Vorsten, waaraan groote bezwaren waren verbonden.

Zoodra Daendels nu de gelegenheíd kreeg trachtte hij een breeder strook in bezit te krijgen. Dit had plaats bij de contracten van 6 en 10 Januari 1811 respectievelijk gesloten met den Soesoehoenan en den Regent van Jogjakarta. Bij art. 2 werd bepaald: „Aan het Hol„landsch Gouvernement wordt bij dezen afgestaan dat gedeelte van ,de Kadoe onder het Solosche (Djocjokartasche) gebied hetwelk bijna ,,tot aan het Noorderstrand loopt doch niet grooter als het gewezen „Regentschap van Candal zich ten Zuijden uitstrekt, zullende van „de Zuijdwestelijke punt van Candal ${ }^{19}$ ) eene parallellinie met de zee ,getrokken worden Westwaarts aan totdat dezelve sluit aan Pacca„longang, welke linie de Grensscheiding zal uitmaken tusschen de „,stranden en de Landen onder de beheering der Javasche Vorsten „,in de Cadoe".

Volgens respectievelijk art. 14 en 15 van deze contracten zou door een gezamelijke commissie deze grens binnen drie maanden na de rectificatie nader worden bepaald en door steenen of houten pilaren worden afgeperkt ${ }^{20}$ ).

Door het aftreden van Daendels als Gouverneur-Generaal op 16 Mei 1811 en de verovering van Java door de Engelschen in Augustus en September 1811 heeft deze gebiedsafstand nooit plaats gehad.

16) Le Moniteur des Indes Orientales et Occidentales 1846/47 le partie blz. 198.

17) Le Moniteur des Indes etc. 1847-'48 1e partie blz. 39.

18) Encyclopaedie van Ned. Indië le druk deel IV blz. $5922 \mathrm{e}$ kol.

19) Ongeveer op $7^{\circ} 9^{\prime} 0^{\prime \prime}$ Z.B. P. P. Roorda van Eijsinga Handboek der Landen Vollkenkunde enz. van Ned. Indië deel III 3e stuk blz. 57.

20) Filet De Verhouding der Vorsten op Java enz. 1895 bijlagen A en B. 
Door Raffles werd deze zelfs ongedaan gemaakt. In het contract van 23 December 1811 met den Soesoehoenan werd nl. bij art. 7 bepaald: ,The Britsh Government restores to H.H. the territories ",wrested from Him by the traety of the 10 January 1811" en in het contract met den Sultan van Jogjacarta (zonder dagteekening en onderteekening) bij art. 7: ,The British Government restores to „H.H. the Provinces of which the Government of Mataram was ",diverted during the administration of Marshall Daendels except that „of Grobogen”, $-^{21}$ ).

$\mathrm{Na}$ de verovering van Jogjacarta door de Engelschen werd op 1 Augustus 1812 zoowel met den Sultan als met den Soesoehoenan een nieuw contract gesloten waarin bij art. 3 werd bepaald: „In considi,ration of the expences incurred by the British Government during ,the late hostilities and of the protection to be thus afforded of his „Person and immidiate Territories, as to the general defence of the „Island His Highness agrees to deliver over to the entire manage,ment and sovereignty of the British Government his share of the „Districts of Cadoe and Pagitan (Patjitan) - " ${ }^{22}$ ).

Kedoe behoorde tot de Nagaragoeng (Nagara agoeng), de „Om„melanden” terwijl de Djabarangkahsche landen tot de Mantjanagoro, het „Buitenland” werden gerekend. De grens tusschen beiden heette wates of rangkah dus betekent Djabarangkah letterlijk „Buiten de „grens” en in hoog Javaansch Djawitori of „Buiten de Poort” d.w.z. „Buiten de grenslijn der Tolpoorten van het eigenlijke Binnen„land" ${ }^{23}$ ).

De Djabarangkahsche landen behoorden dus niet tot Kedoe en bleven een enclave vormen tusschen de residenties Semarang, Pekalongang en Kedoe.

Of het Engelsche Tusschenbestuur nu gemeend heeft zooals wel eens is verondersteld dat deze landen tot Kedoe behoorden en dus eveneens werden afgestaan blijkt nergens uit. De teruggave in 1811 zou het tegendeel doen veronderstellen.

Eerst op 1 Januari 1825 kwamen deze landen op een eigenaardige wijze onder Gouvernements beheer. Bij mondelinge afspraken van de twee Residenten der Vorstenlanden met den Soesoehoenan en de Voogden van den Sultan werden de landschappen Djabarangkah en Karangkobar tegen respectievelijk f 100.000 en f 26.000 huur 's jaars

21) Filet De Verhouding der Vorsten op Java enz. 1895 bijlagen C en D.

22) Filet De Verhouding enz. 1895 bijlagen $\mathrm{E}$ en $\mathrm{F}$.

$\left.{ }^{23}\right)$ Rouffaer Encyclopaedie van N. I. 1e druk deel IV, blz. 590 le kol. 
voor wat betreft de deelen in bezit van die Vorsten voor 30 jaar in pacht afgestaan aan het Gouvernement nadat op 23 October 1824 de twee Rijksbestuurders zelfs voor geheelen afstand gewonnen waren ${ }^{24}$ ).

Deze afstand kreeg voor wat het Jogjasche deel betreft eerst kracht door het sluiten van het contract van 17 Augustus 1826 met den Sultan Sepoe bij zijn derde troonsbestijging waarbij in art. II werd bepaald: ,Ter bevordering van voorschreven oogmerk verklaart Z.H. de Sultan expresselijk bij deze de Djabarangkahsche landen welke ,thans aan het Nederlandsch Gouvernement voor een jaarlijksche ,,som van f 126.000 zijn verpacht, voor zooveel het aandeel van het „Djokjosche Rijk daarin betreft, in vollen eigendom aan het Neder,landsche Gouvernement te cedeeren tegen eene kapitale som van „f 433.333 waarvan de rente à zes procent gelijk staan met de som „,van f 26.000 , zijnde zooveel als het aandeel van het Djokjosche Rijk ,in de bovenstaande pacht van f 126.000 bedraagt : worden wel expres,selijk bij deze gestipuleerd dat gemeld kapitaal van f 433.333 al „dadelijk in mindering van de bovengemelde oorlogskosten ten voor„deele van Z.H. in rekening zal worden gebracht” ${ }^{25}$ ).

Voorloopig werd het afschrift van het gesloten contract den Sultan niet ter hand gesteld daar men vreesde dat het algemeen bekend worden van den inhoud van art. II nadeelig zou werken op het herstel der rust ${ }^{26}$ ).

Eerst bij het contract van 22 Juni 1830 met den Soesoehoenan had de afstand van het Solosche deel dier landen aan het Nederlandsche Gouvernement plaats. In art. 2 van dat contract werd eigenaardig genoeg bepaald dat in die landen ,het gezag van Z. H. den Soesoe,hoenan in zijn naam gevoerd (zou) worden, door het Nederlandsche Gouvernement".

Intusschen makkte het Gouvernement groote haast met de indeeling van de Djabarangkahsche landen en werden ze bij Gouvernements Resolutie van 22 Februari 1825 no. 7 reeds ingedeeld bij het Gouvernements gebied als drie Demangschappen nl. Keboemen onder Pekalongan, Selakaton onder Semarang en Kebondalem onder Kedoe.

Dit zich meester maken van het apanagebied van Djabarangkah zoo kort volgend op de beruchte intrekking der landverhuringen zette

24) Louw De Java Oorlog van 1825-1830 deel I, blz. 18/19.

25) Encyclopaedie van N. I. 1e druk deel IV, blz. 594/595.

2a) A. W. P. Weitzel De Oorlog op Java van 1825 tot 1830 deel I, blz. 406 . 
nieuw kwaad bloed in Solo en het toch al gistende Jogja. Het was een van de oorzaken van het uitbreken van den Java Oorlog op 20 Juli 1825 .

In Mei 1826 schrijft de Resident aan het Hof van Soerakarta in zijn nota dat ,hoezeer hetzelve (het Nederlandsche Gouvernement) van ,die landen reeds bezit had genomen en daarvan de inkomsten genoot ,is de voldoening van de bepaalde pachtschat.... achterwege geble„,ven" en verder ,het niet voldoen der verschuldigde pacht aan de „Vorsten waardoor velen hunner onderdanen ruim anderhalf jaar ,,van inkomsten verstoken zijn geweest heeft veel toegebracht tot het „bereids ontstane misnoegen” ${ }^{27}$ ).

Het overnemen van deze landen was voor het Gouvernement van veel belang en wel voor de afronding van het Gouvernements gebied, een goed politietoezicht en het onderhouden en verbeteren van den nieuwen weg.

Keeren we nu terug tot de verdere geschiedenis van den weg.

Niet alleen gedurende den aanleg maar ook daarna blijkt onder het personeel en de paarden van de poststations veel ziekten voor te komen.

Zoo schrijft de Civil Commissioner Hope op 8 Februari 1812 aan Raffles: „The destructive effect of the climate on the pressant Road ,are so dreadful both to the men and animals of any description.... ,there that the maintenance of it is a serious load upon the country" ${ }^{28}$ ), terwijl in het wekelijksch rapport van Paccalongang do. Februari 151812 wordt vermeld: ,The people employed in the ,different poststations as well as the horses are very sickly not with,standing the former are relieved every week” ${ }^{29}$ ). In 1821 wordt nog gemeld dat op de poststations Karanganjar en Passangrahan 14 van de postpaarden zijn overleden ${ }^{30}$ ).

Ook tijdens het Engelsche Tusschenbestuur bestonden plannen den weg te verleggen, zooals blijkt uit de Order No. 44 Batavia do. 21 Februari $1812^{31}$ ), waarin de commissaris van de wegen Oost van

27) Nota omtrent den Staat der Javasche Vorstenlanden en de bestaande onlusten door H. Mac Gillarry Resident aan het Hof van Soerakarta do. Mei 1826. Handschrift No. 100 van het Koninkl. Inst. voor de T., L. en Volkenkunde van Ned. Indië.

28) 's Lands Oudarchief te Batavia Java's N. O. Kust Varia No. 59.

299 ) 's Lands Oudarchief te Batavia Java's N. O. Kust No. 345.

3o) Index der Algem. Secretarie Buitenzorg 1821 le halfjaar do. 24 April.

31) Proclamations, Regulations, Advertisements and Orders printed and published in the island of Java by the British Government and under its authority. 1813 Vol. I blz: 52 . 
Karangsamboeng wordt opgedragen zonder uitstel een plan en begrooting op te maken voor den ontworpen nieuwen weg door het Pekalongansche district zoodat er geen tijd verloren kan gaan met den aanvang der werkzaamheden bij het eindigen der regens. Uit den bovengenoemden brief van den Civil Commissioner Hope van 8 Februari 1812 blijkt dat de opname van den nieuwen weg was verricht door „Lt Stewart late of the Dutch Engineers”.

Ten slotte is het aanleggen van een nieuwen weg tijdens het Engelsche Tusschenbestuur vervangen door een ander plan nl. het openkappen van het uitgestrekte bosch van Codawan waarvan reeds belangrijke deelen verhuurd waren aan landbouwers die de landen binnen drie jaren zouden omzetten in rijstvèlden ${ }^{32}$ ).

Vermoedelijk heeft dit plan niet veel resultaat opgelevèrd terwijil het strategische bezwaar en het gevaar voor zeeroovers bleven bestaan.

Begin 1819 werd dan ook door den Gouverneur-generaal van der Capellen een algemene opname voor een nieuwen weg gelast en bij Gouvernements Besluit van 4 Augustus 1819 no. 3 werd autorisatie verleend den weg te doen opnemen en uitzetten door den Inspecteur van den Waterstaat J. Tromp en den Landmeter Petersen. Er werd een bedrag van f 20.000 toegestaan terwijl bepaald werd dat indien de op te maken begrooting dit bedrag niet overschreed dadelijk met den aanleg kon worden begonnen. Op 29 September 1820, 4 Mei en 20 Augustus 1821 werden nog respectievelijk f 5000 , f 9000 en f 5000 voor den nieuwen weg toegestaan. Op 4 Mei 1821 werd tevens last gegeven tot het opmaken van een gespecificeerde begrooting der voor dit werk nog te doene uitgaven.

Daar de weg tijdens den aanleg nog liep door het gebied der Vorstenlanden werden voor de uitvoering door de Residenten van Solo en Jogja heerendienstplichtigen beschikbaar gesteld. Zoo werden in Mei 1821 op voorstel van den Resident van Pekalongan tot voltooiing van den weg de Residenten van Solo en Jogja door de Regeering aangeschreven om eenige honderden menschen te doen disponibel stellen en den Resident van Pekalongan erop aandachtig gemaakt of het niet beter zoude zijn dat het werkvolk hunne werkzaamheden uit hoofde van de zware hitte zou staken van 's morgens 10 tot 's avonds 3 uren.

Op den 3den September 1821 wordt de nieuwe rijweg van Batang tot Weleri voor de wagen- en brievenpost opengesteld en is het ge-

32) Java Government Gazette Saturday. 4 December 1813 No. 93. 
bruik van den ouden rijweg door het bosch van Kadawong vervallen ${ }^{33}$ ).

Verder wordt de Resident van Pekalongan op den 10den September 1821 gemachtigd de passangrahans en poststellingen langs den ouden weg te verkoopen ${ }^{34}$ ), terwijl op den 30 sten October 1822 autorisatie wordt verleend tot den aankoop van buffels voor de voornaamste hoogtens langs den nieuwen weg tot bespoediging der passage van de postwagens en de conservatie der paarden ${ }^{35}$ ).

Uit de stukken blijkt dat al was de weg voor het verkeer opengesteld deze nog lang niet voltooid en ten allen tijden berijdbaar was.

In Augustus 1822 wordt de weg voor de eerste maal door den Gouverneur-generaal van der Capellen afgelegd in ruim 4 uren ,een „tijdsbestek hetwelk uit aanmerking der moeijelijkheden welke dit ,terrein oplevert als zeer kort kan worden opgegeven”.

„Die moeijelijkheden zijn desniettemin aan den aandacht van Z. E. „niet ontsnapt en zij heeft zich op de plaats zelve onderscheidene „reizen aanwijzingen laten doen van de middelen door welke alsnog „eenige der moeijelijkste hoogten zouden kunnen worden vermijd „daar het te voorzien is dat zonder voorziening in deze dit kleine ,traject groot oponthoud in de correspdondentie zal kunnen veroor„zaken bij het invallen der Westmoesson, wanneer de zware regens „den weg die thans in goeden staat is, zullen hebben beschadigd" ${ }^{36}$ ).

Door de Vorsten werden niettegenstaande de weg voor het verkeer geopend was nog steeds heerendienstplichtigen geleverd, die in September 18221 katje rijst, $1 / 10$ katje zout en 2 duiten daags ontvingen ${ }^{37}$ ).

In Maart 1823 werden nog gelden toegestaan voor het aanstellen van twee Europeesche mandoers à f 3 daags en den aankoop van 400 patjols, 50 koevoeten, 500 kapbijlen en 150 kapmessen voor de arbeiders ${ }^{38}$ ).

- Reeds in Augustus 1821 werd geklaagd over de trage voortgang van den nieuwen weg en werd in Augustus 1822 de Secretaris der residentie Tagal Koch met de werkzaamheden daaraan belast terwijl

33) Bataviasche Courant van Zaterdag 22 September 1821 no. 38.

34) Index Algem. Secretarie Buitenzorg 1821 2e halfjaar.

35) Index Alg. Secretarie Buitenzorg 1822 2e halfjaar.

36) Bataviasche Courant van Zaterdag 17 Augustus 1822 No. 33.

37) Index Algem. Secretarie Buitenzorg 1822 2e halfjaar.

38) Index Algem. Secretarie 26 September 1822. 
intusschen van den Resident van Pekalongan bij voortduring rapporten werden tegemoet gezien ${ }^{39}$ ).

De Secretaris van de residentie Tegal G. F. Koch kreeg meer dergelijke opdrachten. Zoo werd hij in 1825 uit zijn betrekking ontslagen en benoemd tot adjunct-directeur van de opname voor het samenstellen van een nieuwe verbeterde kaart van Java. Door de bij Koninkl. Besl. van 5 April 1825 No. 96 gelastte bezuinigingen werd deze opname gestaakt ${ }^{40}$ ).

Eindelijk wordt op 18 Juni 1823 door den Resident van Tagal bericht dat de nieuwe weg geheel voltooid is. Maar uit een schrijven van den Resident van Pekalongan van 22 Juli 1824 blijkt dat de opzichter Pietersen nog opzigt houdt aan den Batangschen weg en de werkzaamheden zeer vorderen ${ }^{41}$ ).

Dat de werkzaamheden aan den weg zoo langzaam opschoten zal wel voor een belangrijk deel te wijten zijn aan het feit dat het terrein waardoor de weg liep nog steeds tot het gebied der Vorsten behoorde.

Uit latere berichten van reizigers blijkt ten duidelijkste dat in den weg nog vele steile hellingen voorkwamen. Op een paar poststations werden voor de reiswagen 6 paarden in plaats van de gewone 4 verstrekt om in het ongemak van den weg te voorzien ${ }^{42}$ ). Op verschillende punten moest men gebruik maken van een voorspan van $2-4$ buffels om den wagen tegen de steile hellingen op te trekken. Soms was men verplicht om ,meer dan een uur te midden van een „vrij sterke hitte langzaam voort te stappen in den wagen met 4 ,paarden en 2 buffels bespannen waarmede men dikwijls hoogten moet ,afrijden zonder dat de buffels daarom worden afgespannen aange,zien men dadelijk na de eene berg te zijn afgereden weder eene ,andere moet bestijgen" ${ }^{43}$ ).

De zwaarste was de zg. Plelen-helling die eenige kilometers westelijk van de Kali Koeta begon, meer dan een paal lang was en het vervoer ten zeerste belemmerde.

Reeds vroeg schijnen plannen tot verbetering van deze helling te hebben bestaan. Zoo is hiervan sprake in een nota over de Transportmiddelen op Java van $\pm 1835^{44}$ ) en daarna in de Mindere Welvaart-

39) Index Alg. Secretarie 26 September 1822.

40) S. van Deventer Jsz. Bijdragen tot de kennis van het Landelijk Stelsel op Java, 2e deel 1866, blz. 109 t/m 114.

41) Index Algem. Secretarie.

42) G. H. Nagel Schetsen uit mijne Javaansche Portefeuille $1828 \mathrm{blz} .71$.

43) Tijdschrift voor Ned. Indië 2e jg. 1839, 1e deel, blz. 354.

44) 's Lands Oudarchief Batavia B. O. W. No. 10. 
verslagen ${ }^{45}$ ) waar het een urgente verbetering wordt genoemd.

Dit plan kwam eerst in 1918 toen het werd opgenomen in het Algemeen Wegenplan voor Java tot uitvoering. De omlegging kwam in 1921 gereed, in plaats van de hellingen $1 / 6-1 / 7$ in den ouden weg is de maximum helling nu $1 / 20$. De weg is daardoor $1.5 \mathrm{~km}$. langer geworden ${ }^{46}$ ).

Verder vermeldt het Algemeen overzigt van den toestand van Nederlandsch Indië gedurende het jaar 1846 voor de Residentie Pekalongan: „De verlegging van een groot gedeelte van den weg „loopende door het regentschap Batang ter lengte van 20 palen is in ,.1846 aangevangen en wordt langzamerhand voortgezet, naarmate „over den handenarbeid der bevolking kan beschikt worden. De veel,vuldige arbeid aan de indigotuinen en de heerschende epidemie „hebben aanleiding gegeven om dit werk te doen staken. Wanneer de ,nieuwe weg zal zijn voltooid, zullen op een traject van 7 palen geene „buffels tot voorspan meer behoeven gebezigd te worden, zooals thans „hèt geval is" ${ }^{47}$ ). Vermoedelijk is dit hetzelfde werk waarop Dr. Epp doelt ${ }^{48}$ ). Of hier sprake is van den aanleg van een geheel nieuwen weg dan wel van plaatselijke omleggingen zal later worden besproken.

In 1899 kwam nog een plaatselijke omlegging bij Podjoenkrep (Poetjoengkerep) gereed ${ }^{49}$ ).

Een verdere verkeershindernis was de Kali Koeta op de grens van de residenties Pekalongan en Semarang.

Bij bandjir moest men hier vaak uren ${ }^{50}$ ) tot soms twee dagen wachten voor de overvaart per pont mogelijk was ${ }^{51}$ ). Daarom was op den Pekalanganschen kant een passanggrahan opgericht ${ }^{52}$ ).

Op de bovenvermelde Geographische Landkaart staat bij de kruising van den weg met de $\mathrm{K}$. Koeta een hangende brug aangegeven. Vermoedelijk is dit dezelfde brug waarvan de Chinees Ong Hoe Hoë melding maakt in zijn "Opmerkingen” ${ }^{53}$ ). Hij vertrok in 1783 uit China naar Batavia, vertoefde tien jaren lang in den Archipel en

45) Deel IVa blz. 155

46) Jaarverslag der B. O. W. 1921/24 3e ged. blz. 14/15.

47) Tijdschrift voor N. I. 10e jg. 1848 deel I, blz. 111/12.

48) Dr. Epp Schilderungen aus Holländisch Ost Indiën 1852 blz. 403 en Moniteur des Indes etc. 1847/48, 1e partie, blz. 55.

49) Jaarverslag der B. O. W. 1899 blz. 68.

$\left.{ }^{50}\right)$ J. B. J. van Doren Fragmenten uit de reizen in de Indische Archipel enz. 1e deel 1854, blz. 274.

51) Dr. S. A. Buddingh Neerlands Oost Indië $1859 / 60$ le deel, blz. 159.

52) Tijdschrift voor N. I. 11e jg. 1849 deel II, blz. 268.

53) Tijdschrift voor N. I. 14e jg. 1852 2e deel, blz. 1 e.v. 
schrijft o.m. : „Toen ik van Semarang naar Pekalongan reisde kwam ,ik voor eene rotting brug en daar mij geen ander middel overbleef, „verliet ik mijn rijtuig” ${ }^{54}$ ). Daaruit zou men tevens opmaken dat de weg van Semarang tot de K. Koeta per rijtuig was te berijden.

Ook na de voltooiing van den postweg schijnt hier een brug te hebben gelegen daar in een schrijven van den Hoofdinspecteur van den Waterstaat van 4 Juni 1819 . no. $244^{55}$ ) wordt gesproken over een voorziening van de brug bij de $\mathrm{K}$. Koeta ter voorkoming van verdere inspoeling.

Kort daarop is deze blijkbaar weggeslagen want in een schrijven van den Hoofdinspecteur van 12 Juli 1820 No. $385^{56}$ ) wordt bericht dat de ligging van den brug is bepaald, terwijl de kosten daarvoor gevonden zullen worden uit de bij besluit van 4 Aug. 1819 No, 3 toegestane gelden voor het leggen van den weg van Batang naar de K. Koeta.

Op 11 Augustus 1822 schrijft de Hoofdinspecteur dat het kappen van het hout voor de nieuwe brug over de K. Koeta geen verdere voortgang zal hebben totdat die rivier een vaste richting zal hebben genomen terwijl voorgesteld wordt intusschen daarover een sasak te plaatsen ${ }^{57}$ ), terwijl deze op 23 Augustus 1822 schrijft dat de sasak uit twee gekoppelde prauwpapangs bestaat met een derde in reserve ${ }^{58}$ ):

Junghuhn schrijft over dit veer op zijn reis over Java in eind 1844: „Zooals gewoonlijk het geval is laat men bij het overzetten over een „,dergelijke rivier de paarden afspannen en wordt het rijtuig door „koelies in de veerschuit getrokken. Hiervoor krijgen zij gewoonlijk ,een gulden. Dat is goed betaald”. Een daar gevestigde Chinees die de koelies voorschotten had verleend kwam dit bedrag innen ${ }^{59}$ ).

Het reizen op Java per paardenpost was kostbaar, voor een reis van Batavia naar Semarang betaalde men alleen voor de paarden f 600 , voor het rijtuig moest men zelf zorgen. Maar bovendien moest men talrijke fooien geven aan den koetsier, de voorloopers, de geleider der karbouwen, enz.

Bij de reis van den Gouverneur-generaal de Eerens over Java in

54) Ib. blz. 45 .

55) Index Alg. Secretarie 1819 1e halfj., blz. 513.

56) Index Alg. Secretarie 1820 2e halfj., blz. 251.

57) Index Alg. Secretarie 1822 2e halfj. blz. 253.

58) Index Alg. Secretarie 1822 2e halfj., blz. 254.

59) F. Junghuhn Java $2 \mathrm{e}$ verbet, uitg. deel III 1854, blz. 635 . D1. 104. 
1838 was de sasak voor die gelegenheid voorzien van een fraaie tent ${ }^{60}$ ).

Het duurde tot 1854 voordat dit pontveer dat in 1845 voor $\mathrm{f} 900$ per jaar was verpacht ${ }^{61}$ ) werd vervangen door een Townbrug (houten traliebrug) ${ }^{62}$ ). Voor een geschikte bouwplaats moest de weg met ongeveer een paal worden verlengd. In 1860 werd een ingestorte bekleeding bij die brug hersteld ${ }^{63}$ ).

De bruggen over de andere rivieren en waterloopen hebben blijkbaar weinig moeilijkheden opgeleverd, althans is daarover nagenoeg niets bekend. Oorspronkelijk van bamboe en hout zijn ze geleidelijk door meer permanente constructies vervangen.

Uit de vergelijking van verschillende kaarten van $1819, \pm 1840$, 1855, 1860, 1876, 1878, 1905 en 1912, afstandswijzers van Java (Indisch staatsbl. 1844 No. 21,1862 No. 41) en reisbesschrijvingen blijkt dat de loop van den weg gedurende de 19 e en het begin van de 20 ste eeuw nagenoeg geheel dezelfde is gebleven de bovenvermelde omleggingen natuurlijk uitgezonderd.

Of nu ,de verlegging van een groot gedeelte van den weg" vermeldt in het „Algemeen overzicht van den toestand van Nederlandsch Indië gedurende het jaar 1846" een nieuwen weg betreft waarvan de aanleg is gestaakt dan wel plaatselijke omleggingen daarover ontbreken mij de gegevens.

Enkele schrijvers vermelden hoewel de nieuwe weg reeds voor het verkeer was opengesteld, nog de poststations langs den ouden weg ${ }^{64}$ ).

Beschouwd men de residentiekaart van Pekalongan van \pm 1863 schaal $1: 100.000$ waarop zoowel de oude als de nieuwe weg is aangegeven dan ziet men dat de postweg van Daendels vanaf Batang in noordelijke richting liep en heeft de anonieme briefschrijver blijkbaar niets anders bedoeld dan als tegenstelling van die richting te vermelden dat de nieuwe weg meer zuidelijk liep. Hij schrijft dan ook: "laquelle, peu après, se dirige au sud".

Reeds vroeger is door Stieltjes een dergelijke veronderstelling geuit. Deze schrijft: „De weg van Pekalongan naar Semarang loopt thans ,over een vrij hoog punt in het bosch van Willerie tot +225 à 230

60) Tijdschrift voor N. I. 21e jg. 1859 deel I, blz. 447.

61) Tijdschrift voor N. I. 21e jg. 1859 deel II, blz. 268.

62) Koloniaal Verslag 1854, blz. 93.

63) Kol. Vers1. 1860 bijlage L.

64) P. P. Roorda van Eijsinga Handboek der Land- en Volkenkunde, enz. van Ned. Indië 1841 deel III 1e stuk, blz. 186/89 en J. B. J. van Doren Fragmenten uit de reizen in de Ind. Arch. 1854 deel I, blz. 274. 
„,bij post Sambong. Het hoogste punt beoosten dien post heeft door ,den invallenden nacht niet kunnen waargenomen worden en ligt ver„moedelijk een twintig ellen hooger. Vroeger schijnt de weg door ,vlakker terrein te hebben geloopen. Volgens sommigen volgde de „oude weg van Daendels de kust, maar is om de zeeroovers meer „,binnenslands verlegd. Volgens het rapport van den Hoofdingenieur „Dixon echter van October 1861 heeft de weg een dal gevolgd be,zuiden den thans bestaanden weg en wel van Batang tot Tjilaga „Plelen en zou die weg in den Javaoorlog vernield en later over de „hoogten gelegd zijn. Ik heb de gelegenheid nog niet gehad dit nader „te onderzoeken. Is de oude weg misschien twee malen verlegd, eens „om de zeeroovers, eens om de opstandelingen" ${ }^{55}$ ).

Het is niet juist dat de nieuwe weg die in 1825 door de opstandelingen werd vernield toen is verlaten.

„Op den 14den Augustus 1825 was de post van Semarang naar „Batavia genoodzaakt te Sembong 9 palen O. van Welerie terug te ,keeren en weldra vernam men dat de gemeenschap tusschen de ,hoofdstad en Midden Java geheel gestremd was. Ten oosten en „westen van Welerie was een aantal poststations verbrand en de „,meeste bruggen waren vernield. Intusschen was de luitenant-kolonel „Cleerens, adjudant van den Gouverneur-generaal met 50 huzaren te „Pekalongan aangekomen, ten einde het bevel over de troepen in die „residentie op zich te nemen” ${ }^{66}$ ).

„Op den 24sten Augustus was de postweg door de vereenigde „pogingen van Cleerens en den Assistent-resident van Kendal Holm„,berg de Beckfeld niet alleen van vijanden gezuiverd, maar ook in ,zooverre hersteld, dat het brievenvervoer daar langs weder mogelijk „was. Aan ieder station en bij iedere groote brug werden detachemen„ten van 50 man der hulpbenden van de Regenten van Batang en „Pekalongan geplaatst; de schade aan den weg veroorzaak, was „,echter zoo groot, dat de luitenant-kolonel Cleerens, schoon iederen „dag met 1000 man werkende, hem eerst op den 2den September „weder geheel geschikt zag tot vervoer van rijtuigen" ${ }^{67}$ ).

65) Het rapport van den heer Stieltjes over Verbeterde vervoermiddelen op Java met kantteekeningen van een officier der Genie van het Ned. O. I. Leger 1864 , blz. 7.

66) A. W. P. Weitzel De Oorlog op Java van 1825 tot 1830, 1852 1e deel, blz. 150.

67) Ib., blz. 151 . 
In October werd de veiligheid nog eens voor korten tijd verstoord ${ }^{68}$ ).

Het is mogelijk dat de Hoofdingenieur Dixon den ouden weg van Batang via Soebah en Pakis naar Kendal die onder de Inlandsche Vorsten in gebruik was voor den vroegeren postweg heeft gehouden.

Een gedeelte van den ouden postweg langs de kust is gebruikt voor den aanleg van den tramlijn Semarang-Cheribon.

Hoe woest de streek was toen de nieuwe postweg door het bosch van Weleri werd aangelegd kan blijken uit het verslag van Dr. F. Epp van een door den Regent van Batang in 1829 bij Gringsing ten noorden van den weg gehouden jachtpartij waarbij 3 rhinocerossen en 7 bantengs werden gedood ${ }^{69}$ ).

Den Haag, Juli 1946.

68) Ib., deel II, blz. 290.

69) Moniteur des Indes etc. $1847 / 48$ le partie, blz. 50. 